\title{
Community Involvement in Developing Comprehensive Cardiovascular Control Programs A Case Study in North Karelia, Finland
}

\author{
JAAKKO TUOMILEHTO \\ LIISA NEITTAANMÄKI \\ JUKKA T. SALONEN \\ North Karelia Project \\ University of Kuopio
}

PEKKA PUSKA

AULIKKI NISSINEN

National Public Health Laboratory

\section{Introduction}

During the past decade it was commonly understood that prevention and control of major public health problems should be designed and carried out through existing health services, especially with emphasis on primary health care development. The importance of, and concern for primary health care implementation has been further discussed within World Health Organization and among health officials of its Member States resulting the »Alma-Ata Declaration» in 1978 (1). However, it is realized that the actual implementation of primary health care is a complex issue which proves several challenges.

There are efforts in various countries to develop this kind of approach in order to control their major public health problems. Among these efforts there are attempts to community-based control of cardiovascular diseases. In spite of the most tremendous development of technology and curative services for cardiovascular diseases there could be observed increasing rates of mortality and morbidity due to cardiovascular diseases in developed countries (2). As the multifactorial origin of cardiovascular diseases became obvious and the major risk factors were identified, and as the close link between the risk factors and the lifestyles and environment in the community became apparent $(3,4)$, the next step, i.e. involvement of an entire community in an intervention programs, was at hand (5).

\section{The meaning of the community involvement}

It has been examined systematically what is meant by community involvement 
in the development of health services $(6,7)$. So community involvement includes the following:

(1) Education of the community so that health problems can be identified and understood.

(2) Organization of the community so that group decisions may be taken on health and the community may become self-reliant and accept responsibility for health measures.

(3) Development of a mechanism that allows the community to decide on resource allocation for priority problems. These priority problems may not be health problems and one has to accept the multisectoral nature of the process.

(4) Involvement of the community in a partnership for the planning and implementation of health or health related projects.

Ideally, the community involvement starts with the individual, who learns that he can exercise some control over his own health. This leads to community awareness of health and diagnosis of health or health-related problems. At this stage technical and managerial support can come from outside the community to develop activities that will link up with government programs.

$\mathrm{F}$ i g u r e 1. Illustration of the process of community involvement in health services development. (Modified from WHO: WPR/RC31/TP/1).

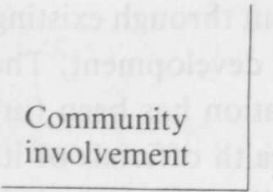

Health
services
involvement

implementation and evaluation

\begin{tabular}{ll|l}
$\begin{array}{l}\text { Individual } \\
\text { awareness and } \\
\text { self-care }\end{array}$ & $\begin{array}{l}\text { Individuals } \\
\text { receptive to } \\
\text { social action. } \\
\text { Organized group } \\
\text { action for health }\end{array}$ & $\begin{array}{l}\text { Community groups } \\
\text { themselves, diagnose } \\
\text { and analyze problems }\end{array}$ \\
$\begin{array}{l}\text { Health and } \\
\text { health-related } \\
\text { national or } \\
\text { intersectoral } \\
\text { demonstration } \\
\text { programs }\end{array}$ & $\begin{array}{l}\text { Managerial and } \\
\text { technical input } \\
\text { from health } \\
\text { services and } \\
\text { other sectors }\end{array}$ & $\begin{array}{l}\text { Health services } \\
\text { and other sectors } \\
\text { infrastructure }\end{array}$ \\
$\begin{array}{l}\text { Project } \\
\text { implemented }\end{array}$ & $\begin{array}{l}\text { Project } \\
\text { initiated and } \\
\text { resources } \\
\text { obtained }\end{array}$ & $\begin{array}{l}\text { Priority problems } \\
\text { indentified. } \\
\text { Resources identified. } \\
\text { Action planned. }\end{array}$
\end{tabular}

The community involvement is a strategy of implementing health care with total coverage of the population, with active participation of the community, with 
organizing resources of the different sectors and coordinating them using technologies to improve and promote the health of the population in the relevant ways to the problems identified. The goal is that the community itself has no longer to be taught to accept or cooperate with given health services but to mobilize community resources in terms of motivation, behaviour and organizations.

In this paper we will describe, how community involvement was used in the North Karelia project, in one of the first attempts of a comprehensive communitybased control for cardiovascular diseases $(5,8,9)$. The aim is to present how existing health problems can be identified and controlled as a part of primary health care development.

\section{The North Karelia Project - objectives and program description}

The main objective was to decrease the cardiovascular mortality and morbidity especially among middle-aged men. The intermediate objectives were to reduce the known cardiovascular risk factors, that is, smoking, serum cholesterol concentration, and blood pressure among the whole population, and to promote early detection, treatment, and rehabilitation of heart disease patients in the community. The national objective was to test the feasibility and effect of this approach and to provide tested methods and programs for national use to control cardiovascular diseases and related health problems. The risk factors were chosen on the basis of information from previous studies, collective international recommendations, and epidemiological data from the area $(5,8,9)$.

Subprograms were planned following the natural course of coronary heart disease and related to smoking, diet, hypertension, coronary heart disease, acute myocardial infarction and rehabilitation. The practical objectives and measures and the recommended built-in continuous evaluation were outlined in each subprogram.

The comprehensive program was integrated into the health and social services of the province. The following elements of the program were started: 1) informating the public; 2) systematic integration of the program to the existing services and creation of the new services; 3 ) training personnel; 4) changing the environment; and 5) internal information services to support the practical activities. The intervention is described elsewhere in detail $(8-11)$.

The strategic objectives of the program, based on the principles presented, can be summarized as follows:

- to influence the combined risk factor levels in the total population;

- to involve the whole community;

- to carry out a systematic program with a carefully planned hierarchy of objectives;

- to integrate program activities into the existing service structure and community social organization;

- to make a baseline community analysis to identify the appropriate measures and strategically important activities; 
- to mobilize the community resources with full involvement and participation of the community;

- to support the mass action with systematic services by reallocating the existing resources to meet the program needs; and

- to have continuous follow-up with feed-back to the community.

\section{The North Karelia project and community involvement}

According to the principles of community involvement it has, in case of the North Karelia project, meant the following:

1) Education of the community so that the existing cardiovascular diseases problem was identified and understood;

2) Initiative for action in preventive measures;

3) Community preparation in order to become self-reliant and accept responsibility for control of cardiovascular diseases;

4) Community action to implement the planned cardiovascular diseases control activities;

5) Continuing involvement of the community.

The development of community involvement in the practical way in the North Karelia project will be described and discussed based on these steps or sequence of events listed above.

\section{Education of the community so that existing cardiovascular diseases problem was identified and understood}

Ideally, community involvement in health promotion starts with the individuals who learn that they should and can exercise some control over their health. The North Karelia project had such an initiative.

\section{Finnish regional differences}

Kannisto (12) described the major impact of cardiovascular diseases on public health in Finland in 1947. He also reported higher rates in Eastern (where North Karelia locates) than Western Finland. Keys (4) and Karvonen using one sample from East and one from West Finland also confirmed the East-West differences in cardiovascular diseases rates. The regional differences in Finland in mortality and morbidity (cardiovascular and all-cause) in the 60's and the beginning of the 70's were studied by many other investigators. The higher mortality rates in Eastern Finland were noticed by Härö (13) and by Leppo and co-workers (14), who also found that these regional differences increased in the 60 's . Mortality statistics further revealed that cardiovascular diseases were the major contributor to these great regional differences (15). The regional differences and the high rates in Eastern Finland were also present in national health interview studies (16) and in statistics of national sickness benefits and disability pensions (17). Ironically, North Karelia 
was the first province in Finland where a modern, well-designed and well-equipped regional central hospital was built in 1952 .

The high cardiovascular diseases mortality rates (59\% among all males, $53 \%$ among all females of all deaths) before the project were, of course, noticed by the North Karelian people - almost every family had experienced somehow the disaster of cardiovascular diseases. This lead to community awareness of the health problems and the understanding of the heavy burden of cardiovascular diseases in this population. However it took a long time and many epidemiological studies were needed to awake this awareness before the community was ready for action. In addition, national statistics on mortality and disability pensions were available for a long time.

\section{Initiative for action}

The governor, all North Karelian members of the national parliament and several representatives of official and voluntary organizations in the area signed in 1971 a petition for national aid to reduce the cardiovascular problem in North Karelia. The paper noted the very high cardiovascular diseases frequency in the area and proposed that national authorities and organizations concerned »should urgently undertake efficient action to plan and implement a program which would organize and finance general health information to the public, necessary basic research, and individual health education to reduce this greatest public health problem of the province». This petition is the necessary start of the community involvement that dictated the future approach of the program and was truly based on the entire community. First of all, participation rates in the baseline survey in 1972, as well as in many subsequent surveys later on, was above $90 \%$ (8). After two weeks in an additional interview $97 \%$ of the responders of the baseline survey considered this kind of surveys useful and $96 \%$ indicated that they would participate again, a survey in a few year's time. More than half wished the re-examination already during the next two years which indicates clear positive personal attitudes on immediate action (Table 1).

T a b l e 1. Proposed interval for a possible re-examination among a sample of the participants to the baseline survey of the North Karelia Project in 1972.

$\begin{array}{lcc}\text { Proposed interval } & \begin{array}{c}\text { Men } \\ (\mathrm{n}=582) \\ \%\end{array} & \begin{array}{c}\text { Women } \\ (\mathrm{n}=639)\end{array} \\ \begin{array}{l}\% \text { years } \\ 1-2 \text { years }\end{array} & 57 & 52 \\ 3-\text { years } & 24 & 20 \\ \text { Total } & 19 & 28 \\ & 100 & 100\end{array}$


Furthermore, $80 \%$ of the responders reported that there would be also other members in their families, who would like to participate. Altogether, $82 \%$ of the men and $66 \%$ of the women considered cardiovascular diseases among all diseases as the most important issue of screening programs in North Karelia.

\section{Community preparation to become self-reliant and accept responsibility for control of cardiovascular diseases}

At the planning stage of the project, a working group reviewed the situation through contacts with national and international experts and in close cooperation with local health services. The need for technical and managerial support from outside was found necessary in order to priority problems identified, to identify the resources and to develop further plan of action required.

From the very beginning, the planning group concluded that a practical serviceoriented program serving the whole community was required rather than only to improve the clinical services or to continue with the observational epidemiological surveys.

Finnish Heart Association convened a planning seminar in 1971, which reviewed the existing information on cardiovascular diseases epidemiology, the North Karelian population and its living conditions, the lifestyles and attitudes of the local population, the structure and resources of health services, and the opinions of the local health personnel. At the end of the seminar, the participants recommended that a comprehensive community-based cardiovascular diseases control program should be launched in North Karelia. This was considered pioneering work.

The limitations of North Karelia were discussed in details in the planning seminar. It was well-known that this country was the least developed area in Finland according to the most criteria used. Table 2 shows it clearly.

Availability of health services resources in the community sets normally also limits to development. Also from this point of view North Karelia was in an unfavourable situation in 1972 . The number of physicians being 0.66 per 1000 population whereas in South Finland it was 2.14.

In the planning phase it was considered important to strengthen managerial capabilities for planning and organizing community activities and community involvement were included the following steps:

1) Development of leadership in the community.

2) Development of a community organization able to take decisions on health matters dealing with cardiovascular diseases control in the area.

The leadership of the project was given to the Board of Directors under the chairmanship of the governor of North Karelia with the assistance of the Steering Committee directed by the Province Medical Officer. The Coordinating Centre was established also at the Department of Public Health, University of Turku (later moved to University of Kuopio).

Later on the Steering Committee defined four working groups for: (i) The 
$\mathrm{T}$ a b 1 e 2. Selected social and economic indicators in North Karelia, reference area and the whole country at onset of the program.

Indicator

Year

1972

Mean population (thousands)

Proportion of working-age people aged $15-$

$64(\%)$

Net migration of population aged $15-44(\%)$

Persons per room in one household

Proportion of people over 15 years with

more than basic school education $(\%)$

Proportion of economically actice people

engaged in agriculture or forestry $(\%)$

Annual income (under taxation) per inhabi-

tant, FMK

Number of cars per 100 inhabitants

Number of telephones per 100 inhabitants

Proportion of working-age people receiving

disability pension $(\%)$

Proportion of people receiving social assist-

ance $(\%)$

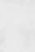

$\begin{array}{rrrr}1972 & 66.1 & 65.8 & 66.9 \\ 1972 & -2.9 & -1.8 & 0.1 \\ 1970 & 1.3 & 1.2 & 1.0 \\ 1970 & 19.1 & 21.6 & 25.3 \\ 1970 & 39.4 & 34.2 & 20.3 \\ 1972 & 3824 & 4156 & 5771 \\ 1972 & 14.9 & 14.3 & 17.7 \\ 1972 & 17.4 & 20.7 & 30.5 \\ 1972 & 11.4 & 9.6 & 6.6 \\ 1972 & 6.3 & 6.2 & 5.5\end{array}$

$\begin{array}{ccc}\text { North } & \text { Reference } & \text { Whole } \\ \text { Karelia } & \text { Area } & \text { Country }\end{array}$

$\begin{array}{lll}181 & 253 & 4639\end{array}$

Health Education; (ii) The Stroke Register; (iii) The Myocardial Infarction; (iv) The Hypertension Control.

Through this planning work, both members of the community and health workers were prepared - the former became aware of the special health problem and the potential for development through a community action; the latter learned about the real needs of the community and their changing role. Although the initial petition was seriously asking for national help to come over the urgent cardiovascular diseases problem, it was finally found that the province could be selfreliant and take the major responsibility of the forthcoming cardiovascular diseases control program.

\section{Community action to implement the planned cardiovascular diseases control activities}

Community action in this sense, bacause of the need for lifestyle changes, meets both:

(i) communication with the health services, and

(ii) communication with the other sectors of the community.

Much of the preparations were carried out in North Karelia by the community itself and the health service system with the support of the organized project team. 
The task of the North Karelia Project was to strengthen the existing structure for health care and within the national guidelines to tackle the cardiovascular diseases problem. This was done through preoccupation of the health workers as well as of the community developers and policy makers.

In order to try to measure community involvement and action in the North Karelia Project, the following indicators could be used:

a) Health resource allocation for cardiovascular diseases control,

b) Personal health habits of the people,

c) Participation of community decision makers in the management of cardiovascular diseases related health services,

d) Communication between the community and the health workers concerning cardiovascular diseases control,

e) Activities carried out by the community.

These indicators will be discussed in the following paragraphes based on the information that was collected during the program.

A) Health resource allocation for cardiovascular diseases control

Existing service activities were used and strengthened and new elements were created when necessary, after analyzing the function of activities. Primary health care provided through local health centres were in key position. Every physician and public health nurse was asked to help modify cardiovascular diseases risk factors among all patients and clients. These activities included inquiry about the smoking history, advice to quit, inquiry and advice on dietary habits, possible serum cholesterol measurement, blood pressure measurement and advice to heart disease patients.

The new cardiovascular diseases prevention activities increased the work of the public health nurses more than that of doctors, who acted as medical advisors and support personnel. However, especially development of hypertension control gave considerable amount of work to doctors, too. Here we describe health resource allocation for cardiovascular diseases control in two ways; first, assessing health workers participation and secondly, assessing costs allocated to cardiovascular diseases control during the entire study period. A matched reference community was used in order to compare the situation in North Karelia to the normal development in the country (8). The survey among health workers was carried out in 1977 by mail which limited the kinds of information that could be obtained (18).

In North Karelia both physicians and public health nurses were more active in health education than their colleagues in the reference area. In general, public health nurses were more active health educators than physicians (Table 3).

Biannual follow-up surveys were carried out during the five-year intervention period to obtain rapid feed-back from the program in North Karelia and to monitor the community changes. Independent random samples, $3.5 \%$ of North Karelian population ages $25-59$ were used in these postal surveys (8).

The proportion of people who had received personal health counselling from a doctor or from a public health nurse during the preceding year increased two- to four-fold during the program (Table 4). 
$\mathrm{T} \mathrm{a} \mathrm{b} \mathrm{l} \mathrm{e} \mathrm{3.} \mathrm{Participation} \mathrm{of} \mathrm{physicians} \mathrm{and} \mathrm{public} \mathrm{health} \mathrm{nurses} \mathrm{in} \mathrm{antismoking}$ and dietary health education in North Karelia and reference area in 1977.

Activity

Physicians

$\begin{array}{cc}\text { North } & \text { Reference } \\ \text { Karelia } & \text { area } \\ \% & \%\end{array}$

Asks most of the patients about their smoking habits

Recommends stopping smoking to every smoking patient

Has personally given, several times, antismoking health education material to smoking patient

Has placed antismoking health education material in the patient's waiting room

Has spoken about smoking in health education meetings at least a couple of times Has acted for restriction of smoking in public places

Advises daily several patients about their diet

Has given several times health education material about cholesterol reducing diet to the patients

Has spoken about healthy diet in health education meetings at least a couple of times Size of the group (n)
44

39

31

53

33

22

36

64

26

115
37

38

10

35

27

17

25

50

22

239
Public Health Nurses

$\begin{array}{cc}\text { North } & \text { Reference } \\ \text { Karelia } & \text { area } \\ \% & \%\end{array}$

74

49

74

65

87

61

94

92

$51 \quad 46$

$29 \quad 26$

$55 \quad 56$

71

59

61

61

154

186

$\mathrm{T}$ a b 1 e 4. The proportion of the population (\%) in North Karelia who had recently received cardiovascular diseases prevention advice from health personnel, by year and sex.

Time

Autumn 1972

Spring 1973

Autumn 1973

Spring 1974

Autumn 1974

Spring 1975

Autumn 1975

Spring 1976

Autumn 1976
Advice from a doctor

Men Women

10

13

21

32

32

27

26

26

29
Women

10

16

17

22

25

24

21

19

20
Advice from a public health nurse Men Women

7


$\mathrm{T}$ a b 1 e 5. The proportion of the population in North Karelia and the reference area who had received personal advice to stop smoking or to change diet during the year preceeding the terminal survey.

$\begin{array}{ll}\text { North Karelia } & \text { Reference area } \\ \text { Men Women Men Women }\end{array}$

$\%$ receiving advice From

$\begin{array}{lllll}\text { a doctor } & 21.6 & 12.3 & 20.2 & 7.9\end{array}$

To stop smoking

(smokers only)

a public health nurse

$\begin{array}{lllll}\text { or occupational nurse } & 20.2 & 12.8 & 9.8 & 6.3\end{array}$
a doctor
12.4
9.9
9.8
8.1

To change diet for prevention or treatment of CVD

a public health nurse

or occupational nurse

$\begin{array}{ll}15.0 & 10.2\end{array}$

6.1

5.2

$\mathrm{T}$ a b 1 e 6 . Measurement of blood pressure of the hypertensives by various types of health personnel during the year prior to the terminal survey (1977) in North Karelia and the reference area.

Blood pressure measured by

Physician

Nurse at health centre

Nurse at home

Auxiliary person

$\begin{array}{cc}\text { North Karelia } \\ \text { Men } & \text { Women } \\ \% & \%\end{array}$

$57 \quad 63$

$48 \quad 64$

$11 \quad 16$

$39 \quad 26$

\begin{tabular}{|c|c|}
\hline \multicolumn{2}{|c|}{ Reference area } \\
\hline Men & Women \\
\hline$\%$ & $\%$ \\
\hline 54 & 62 \\
\hline 38 & 56 \\
\hline 8 & 15 \\
\hline 24 & 18 \\
\hline
\end{tabular}

The individual health counselling increased most among males. Half of it was given by a public health nurse. This was in accordance with the program aims. North Karelian people had received more advice to stop smoking than people in the reference area (Table 5).

Resource allocation for blood pressure control measurements and reorganizing them using more often other health personnel than doctors had been successful. In general, blood pressure had been measured more frequently in North Karelia (Table 6).

The overall health service operation costs, according to official statistics, in North Karelia and the reference area from 1972 to 1977 totalled 215 million USD and 344 million USD, respectively. These costs were per inhabitant 1.2 and 1.3 USD, respectively.

Table 7 gives an idea about changes that have taken place in direct community 
$\mathrm{T} \mathrm{a} \mathrm{b} \mathrm{l} \mathrm{e} \mathrm{7.} \mathrm{Changes} \mathrm{in} \mathrm{estimated} \mathrm{total} \mathrm{health} \mathrm{services} \mathrm{costs} \mathrm{and} \mathrm{in} \mathrm{costs} \mathrm{due} \mathrm{to}$ CVD control in primary health care between 1972 and 1977.

Item

North Karelia

Reference area

Health services operation costs (1000 USD)

1972

18225

55250

27525

1977

$+203.2 \%$

88650

Change 1972-1977 (\%)

$+222.1 \%$

Proportion of visits to doctor due to CVD

out of all visits $(\%)$

1972

42.5

35.5

39.0

38.5

Change 1972-1977 (\%)

$-8.2 \%$

$+8.5 \%$

Costs of CVD visits in primary health care

(1000 USD)

1972

636

1977

1835

858

Change 1972-1977 $(\%)$

$+288.5 \%$

2701

CVD drug costs (1000 USD)

1972

1300

$+314.8 \%$

1977

4224

2124

5967

Change 1972-1977 (\%)

$+324.9 \%$

$+280.9 \%$

costs used for cardiovascular diseases control activities. The annual inflation rate, averaging $10 \%$ has not taken into account. The limitations in cost assessment in this study has been discussed elsewhere (8). During the program health services operation costs - overall or related to visits to primary health care - in North Karelia did not increase. In contrast there were some indications that resources were used more rationally than in the reference area. The greater increase in drug costs in North Karelia can be explained partly by the intensified hypertension control program and partly by the secondary prevention program.

In addition, there were direct project costs - those costs that were associated with the intervention and evaluation of the North Karelia Project. These were the only extra costs that were used in North Karelia to catalyze the process in the community with its existing resources to lead to the desired outcome. Over nine year period 1971-1979 a total 1.2 million USD was used to cover those expences of planning, research and intervention promotion that could not be recovered from other sources.

About $58 \%$ of the budget went for evaluation. The rest, approximately 726000 USD was allocated for intervention covering for instance: salaries for some project staff; health education and training materials; training seminars for local personnel.

B) Personal health habits of the people

Trends in health behaviour related to the program objectives were monitored through in North Karelia from 1972 to 1977 in the population aged 25 to 59 at the time of each survey. 
The proportion of current male smokers declined from $52 \%$ to $43 \%$ during the first intervention year and after that remained stable. The proportion of female smokers (12\% in 1972 and $9 \%$ in 1977) changed a little only at the end of the fiveyear period (Figure 2 ). The daily number of cigarettes smoked by the current smokers remained much the same throughout the period among both men and women. However, attempts to stop smoking increased continuously during the program period.

F i g u r e 2. Trends from 1972 to 1977 in the proportion of smokers in North Karelia and that of smokers who reported having tried to stop smoking during the preceding year by gender.

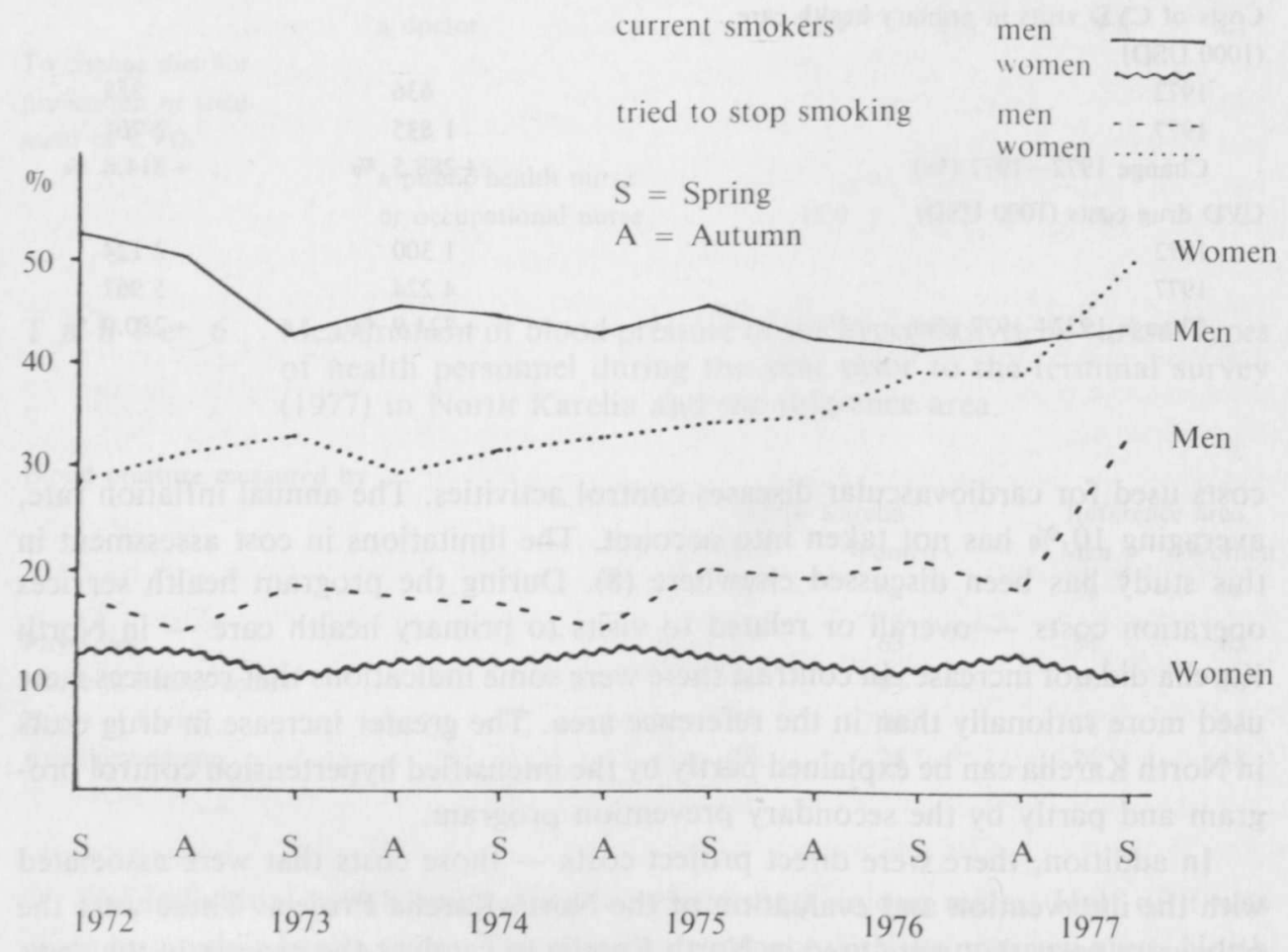

The proportion of men who drank whole milk or market milk decreased during the period, from $69 \%$ to $41 \%$ and that of women from $63 \%$ to $32 \%$ respectively, and the proportion of people who drank low-fat or skim milk increased. During the last year there was a slight tendency to change back from low-fat to market milk. This was associated with a national increase in low-fat milk price in summer 1976.

At the outset $86 \%$ of the men and $81 \%$ of the women reported that they used mainly butter on their bread. During the first three years of the program there was a constant trend among both sexes to change over for soft margarine.

Some improvements in personal health habits required the necessary resource 
allocation to services that were aimed at increasing the personal awareness and estimating personal cardiovascular diseases risk level. Such were for instance serum cholesterol and blood pressure measurements.

Less than $20 \%$ of people had had their serum cholesterol measured within 5 years in 1972 and this percentage increased to $50 \%$ in men and to $43 \%$ in women during the program period. However, the proportion of people whose serum cholesterol had been measured during the preceding six months increased only slightly (in men from $8 \%$ to $15 \%$ and in women from $6 \%$ to $10 \%$ ). Thus, although the intensity of serum cholesterol measurements remained the same, the coverage in the community increased because different people were being examined.

The proportion of all people in the community who were aware of having an elevated serum cholesterol level increased constantly: the proportions increased among men from $7 \%$ in 1972 to $22 \%$ in 1977 and among women from $6 \%$ to $18 \%$, respectively (The baseline survey confirmed that $15 \%$ of the men and $13 \%$ of the women had elevated serum cholesterol levels in the population).

Blood pressure measurements increased in the area most markedly during the first half of the five-year period. The proportion of men whose blood pressure had been measured during the preceding six months prior to each survey increased from $28 \%$ in 1972 to $56 \%$ in autumn 1974 and remained around $50 \%$ throughout the remaining period. Among women there was a higher initial level, and the respective figure reached about $60 \%$. This high frequency of blood pressure measurement in North Karelia resulted in practically every adult having his or her blood pressure measured. Since autumn 1974 almost $100 \%$ of the population had their blood pressure measured within the last two years.

The proportion of men who had been told they had elevated blood pressure in-

T a b l e 8. Trends from 1972 to 1977 in proportion $(\%)$ of men and women in North Karelia aware of their elevated blood pressure and under antihypertensive drug treatment.

\begin{tabular}{ccccc} 
Time of survey & \multicolumn{2}{c}{$\begin{array}{c}\text { Aware of elevated } \\
\text { blood pressure }\end{array}$} & \multicolumn{2}{c}{$\begin{array}{c}\text { Antihypertensive } \\
\text { drug treatment }\end{array}$} \\
& $\begin{array}{c}\text { Men } \\
\%\end{array}$ & $\begin{array}{c}\text { Women } \\
\%\end{array}$ & $\begin{array}{c}\text { Men } \\
\text { Women }\end{array}$ \\
& 16 & 36 & 3 & $\%$ \\
1972 Spring & 20 & 31 & 5 & 9 \\
Autumn & 22 & 33 & 5 & 11 \\
1973 Spring & 19 & 25 & 5 & 10 \\
Autumn & 23 & 26 & 8 & 11 \\
1974 Spring & 24 & 28 & 9 & 15 \\
Autumn & 27 & 32 & 10 & 15 \\
1975 Spring & 27 & 29 & 10 & 14 \\
Autumn & 27 & 29 & 10 & 14 \\
1976 Spring & 30 & 29 & 12 & 13 \\
Autumn & 32 & 40 & 10 & 15 \\
1977 Spring & & & &
\end{tabular}


creased throughout the period from $16 \%$ in 1972 to $31 \%$ in 1977 . Among women the initial awareness was already quite high, $36 \%$, and it was $40 \%$ in 1977 . The proportion of men who were under antihypertensive drug treatment increased considerably: from $3 \% 1972$ to $10 \%$ in 1977 . The »saturation point» was achieved in spring 1975. Among women the initial treatment level was higher (9\%), but reached also the final level earlier: $15 \%$ treated by autumn 1974 (Table 8).

The health knowledge concerning cardiovascular diseases and its risk factors was also assessed in 1972 and 1977 surveys. The health knowledge tests included 24 precoded questions belonged to four categories: 1) smoking, 2) diet and cholesterol, 3) physical exercise, and 4) blood pressure and treatment of heart disease. An additive score was computed for all questions together (19).

In 1972, the health knowledge level was lower in North Karelia than in the reference area, but during the program the North Karelians increased their knowledge more than people in the reference area so that the differences disappeared in 1977 (Figure 3). There was a net increase in North Karelia in health knowledge of $3.8 \%$ among men and $2.3 \%$ among women.

Initially, people with higher estimated risk had somewhat lower health knowledge levels. In all coronary heart disease risk categories the initial level was higher in the reference area. The North Karelians tended to reach the reference group levels except among the very highest category of coronary heart disease risk.

C) Participation of community decision makers in the management of the cardiovascular diseases related health services

Fig u r e 3. Mean total health knowledge scores in North Karelia and the reference area in 1972 and 1977 by gender.

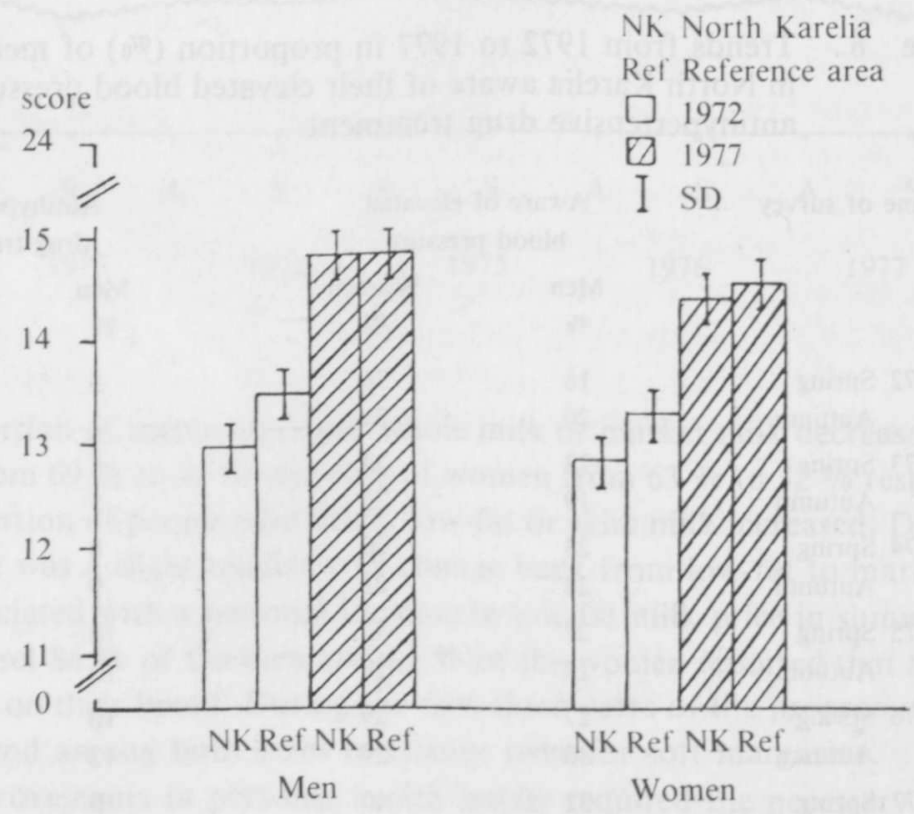


The local administrative unit in implementing the program was the health centre. The local councils, executive and health boards of the health centres made the formal locations the work at the health centres. The chief physicians and chief public health nurses managed day-to-day program operation at local level. The province health administration emphasized that the main program activities should be included in the health centre official five-year plans. To instruct, ensure and check the activities, the Province Health Department staff and the project staff visited regularly the health centres and met health personnel and decision makers there.

In 1977 surveys the local decision makers and the health personnel were asked how adequate the cardiovascular diseases control program were in their own health centre (18). There was a clear difference between two counties: The North Karelian subjects were more satisfied with the cardiovascular diseases control activities than their collegues from the reference area. Opinions about health centre services not linked with cardiovascular diseases control in North Karelia were about the same as those in the reference area. Interesting finding was that in North Karelia, but not in the reference area, the decision makers found still space to strengthen cardiovascular diseases control activities compared to the health workers.

D) Communication between the community and the health workers concerning cardiovascular diseases control

The historical background of the North Karelia Project showed clearly that the communication between the community and health personnel can lead to desired outcome. During the intervention lay persons and voluntary non-medical organizations did much work. They participated actively for instance in the Health Education Committee's work.

The project participated in the North Karelian fair in Joensuu in 1974 (with 100.000 visitors), in an agricultural fair in Joensuu in 1976 and in two small exhibitions in Joensuu in 1975 and in Outokumpu in 1976. The project both usually gave blood pressure measurements and had health knowledge competitions, slide shows and health education material.

Campaigns were arranged throughout the study period. Usually one or several other organizations or institutions were involved in activities serving the project goals. These usually increased health information available to the public and were supported by mass media. Usually the project made the basic plans and outlined the necessary material while the other participants took care of the practical campaign implementation. Typical campaigns were health days at schools, "Fathers' day» campaigns, nutrition campaigns at occupational canteens, writing competitions for housewives, antismoking campaigns at garrisons, campaigns for planting vegetables in spring, and campaigns for non-fat milk at shops.

The survey among decision makers showed the North Karelian decision-makers had more often received personal advice from health personnel to stop their smoking or to change their dietary habits than their counterparts in the reference area. North Karelian public health nurses especially had been more active towards the decision-makers than their colleagues in the reference area (Table 9). 
$\mathrm{T}$ a b 1 e 9. Proportion (\%) of decision-makers who reported having received advice on health behaviour during the previous year by area and type of advice and type of health personnel.

$\%$ reported having received

To stop smoking

- from a physician

- from a public health nurse

\section{North Karelia Reference area}

$31 \quad 18$

$30 \quad 10$

n (decision-makers who had been smoking during the preceeding year)

To change dietary habits

- from a physician

16

13

- from a public health nurse

22

8

$\mathrm{n}$

As regards the survey among health workers the North Karelian health personnel was more active in contacts with various organizations than the reference area personnel (Table 10). This was especially true for contacts with the Province Health Department, local decision-makers and voluntary health organizations. In general, the public health nurses had more contacts than physicians with all organizations except the mass media.

$\mathrm{T} \mathrm{a} \mathrm{b} \mathrm{l} \mathrm{e} 10$. Active contacts by physicians and public health nurses with institutions and groups to promote public health by area and type of institution or group in 1977.

Has been in contact with

\begin{tabular}{cccc}
\multicolumn{2}{c}{ Physicians } & \multicolumn{2}{c}{ Public Health Nurses } \\
North & Reference & North & Reference \\
Karelia & area & Karelia & area \\
$\%$ & $\% 0$ & $\%$ & $\%$
\end{tabular}

County health department

$\begin{array}{ll}46 & 29\end{array}$

Local decision makers

56

29
43

$\begin{array}{ll}75 & 48\end{array}$

Voluntary health organizations

44

66

Other organizations

Schools

Shops

Food industry, dairies etc.

News media

24

E) Activities carried out by the community

The analysis of the North Karelian newspapers showed that altogether 1509 articles were published on the project, cardiovascular diseases risk factors or cardiovascular diseases control during the five-year intervention period. This was, on the average, one article every second day. 
A substudy obtained data from an $11 \%$ randomly selected days on articles in newspapers in North Karelia and in the reference area. The number of articles in North Karelia was about three-fold and the total length of these articles more than four-fold than those in the reference area. The trend matches the previous data for North Karelia.

Voluntary organizations participated actively in cardiovascular diseases control their own ways. The housewives' organization (the "Martha Association») contributed especially organizing nutrition health education. Some of the adult education institutions delivered courses on smoking cessation, nutrition, etc.

Good examples on environment modification were new low-fat products that were developed and introduced by local dairy and a local sausage company. The project supported these attempts in the health education campaigns.

Lay health educators were trained by the project in some local communities towards the end of the period. The community itself prepared an opinion leader list for each village involved this activity. A special survey among these persons (20) showed that they were active involved in their local communities and interacted frequently with other community members. For instance $82 \%$ of them stated other persons reacted in a positive way to their discussions about prevention of cardiovascular diseases.

\section{Discussion}

In this discussion, we consider some issues and implications of our experiences to develop health services and other community activities for cardiovascular diseases prevention as well as for control of other major public health problems. Thus, the following aspects need to be discussed:

1) health as a priority; 2) health as a national or regional policy; 3 ) how to sustain community involvement; 4) when is the community ready; 5) the long process of community involvement; 6) coordination between the sectors; 7) information services as a factor in the program; 8) changed role of health workers and; 9) impact on health.

\section{Health as a priority}

It has been noted that economic development and other sectors are of more concern than health. This was seen also in North Karelia. In 1952 the community had invested in a modern and well-equipped district hospital which was tought to help in cardiovascular diseases control in the province. Therefore, the initiative to start cardiovascular diseases prevention activities in North Karelia really indicates that North Karelia people understood that high priority must be given to solve their major health problem. In fact, North Karelia as the least developed area in Finland had many other urgent needs. We should see this attempt as a case where health sector was asked to take leadership, through linking health needs with other needs in the community, in developing an order to seek for a new future for this depressed 
population. At the same time, new national public health legislation confirmed without doubt these attempts.

The heavy emphasis on the program development by the North Karelian people was so obvious that the desirable outcome was achieved during a short planning phase. This, on the other hand, shows that when the community seriously takes up its health problems and gives them a high priority, a partnership with health authorities and related research institutions is likely to be high, too.

\section{Health as a national policy}

The new public health legislation in Finland was discussed for a long time. It was found that health services in the previous set up cannot co-operate with new major public health problems e.g. cardiovascular diseases. Therefore, the community action for the development of national health policy was very timely. The North Karelia project was, shortly after its establishment, officially considered as a program where the actual content and working methods concerning cardiovascular diseases in the newly established health centres were developed and tested.

One main aim was to find out how existing health services and other community resources could be used to control new epidemics of noncommunicable diseases. The resources in North Karelia at the time of program planning and implementation were smaller than in other regions of the country. The additional costs were taken care by the national health authorities. For comparison, the direct project costs for eight year planning and intervention period were equivalent to the operation costs of only four to five beds in a Finnish unversity hospital. In any event, it is questionable whether the project caused any net costs to North Karelia or to health care system at all. Certain savings, e.g. disability pension rate decrease, indicate large savings for the community (21). Thus, this investment seemed to be rather costeffective. So lack of resources should not be a problem for the feasibility of a similar program in any other part of the country. On the other hand, if the resources in North Karelia for the project would be greater - let's say similar than they were in Finland at the end of the project on the average - a more intensive and quicker intervention implementation could probably have taken place.

Already towards the end of the initial program period, planning and practical work took place to apply many of the experiences gained in North Karelia on a national level. These included national health education committee, national blood pressure committee, antismoking legislation, development of health education materials, national programs of voluntary organizations, etc. Through the national five-year health planning the Finnish Government is able to use the North Karelian experiences continuously.

\section{How to sustain community involvement}

Several examples have shown that to develop such involvement is relatively easy, but to maintain it as a permanent and dynamic process is much more difficult. The North Karelia population participated eagerly in the program from the very beginn- 
ing. The original enthusiasm was used for the first actions to develop public information to ensure participation and program coverage.

Resource limitation, in addition to general principles, led into great emphasis on the participation of community organizations and individuals. This probably increased the community involvement during the program. During the program considerable resources were used to develop and provide feed-back about the program to the lay population and local health personnel. Although it is good to have a detailed program description covering the whole period - as was also case in the North Karelia project - certain flexibility, based on feed-back from the community, may be important to sustain community involvement. New activities were introduced gradually throughout the entire period. It has been shown that new ideas often must travel through several steps of interpersonal communication to reach the entire population.

The project was able to attack intense and frequent attention from the news media in the province. Concrete tasks, such as distributing health education material, organizing health education meetings were to stimulate the involvement of voluntary organizations and individuals. This kind of activity is known to introduce changes in attitudes and beliefs. Other forms of persuasion were used as well - individuals were often urged to make lifestyle changes not for themselves but for North Karelia.

In the preventive programs it is especially important to accompany all messages to the people with simple and practical advices that people can individually follow. Unlike benefits from curative efforts in medicine are self-explanatory to individuals, benefits arising from preventive measures are not so clear. This emphasized the importance of information services that provided continuously important points and developments of the program. The significant increase in health knowledge demonstrate the effectiveness of this information campaign. And finally, $90 \%$ participation rates to the surveys, etc. throughout the period tell in its way that the community was enthusiastic still at the end of the period.

Already towards the end of the initial program period, it became obvious that the program should not be stopped in North Karelia. The community felt that continuation was important and the country administration and project team concurred. In spite of the positive results, it was understood that North Karelia project's five-year period was only the beginning of the road. In 1977, the continuation protocol was accepted by the representatives of the community and health sector and the Province Governor appointed a new Council to guide the program continuation based on the previous principles.

\section{When the community is ready}

It has been learned that a community will not, and cannot be involved in health services merely because health sector has decided it needs the community to participate. Therefore, there is a process, often long, of preparing the community; it would be better to say the community has to prepare itself. As described above 
knowledge about the unfavourable situation concerning cardiovascular diseases in North Karelia cumulated over 20 years until the awareness resulted a community action. It was a process of epidemiological and other investigations and learning process through other health programs that were implemented previously in North Karelia. Finally, the readiness of North Karelia to start with the programme was confirmed in the planning meeting which formalised the forthcoming action. However, it was not at all sure whether the poor socioeconomic situation and rapidly changing social organization in North Karelia would be constraints for the program.

\section{Involvement may be a long process}

It may need several years, even longer than the five years of the North Karelia Project, while enough experience is being generated to allow final conclusions on community-based control of cardiovascular diseases to be formulated. All elements were introduced gradually in North Karelia. Ignorance and firmly held beliefs were tried to overcome by continuous education and persuasion. In fact, only at the end of the program many planned activities were working at the desirable level. Thus, the evaluation of the program effects can only answer to the question, what happens during developing period of such a community program. It is important to separate short-term and long-term needs when the results and experiences will be used elsewhere.

The importance of different strategies is well seen for instance in the gradually increasing trend of low-fat milk which was completely nullified by the national price policy over one night. Health education campaigns can never compete with such a national policy - the only way is to find common goals and strategies. That, however, requires a certain level of community involvement.

Finally, cardiovascular diseases is a result of lifestyles during decades, starting from childhood. Therefore, the ultimate solution in prevention should also be based on such an long-term approach. Changing lifestyles may require new generations to be grown, educated in right ways. This led in North Karelia also to introduce more systematic itervention measures for children in North Karelia after the initial fiveyear period $(22,23)$.

\section{Coordination between the different sectors of the community}

The project organization was tried to develop a great degree intersectoral coordination, based not only at high levels of administration in various councils and committees but also at local levels of various social, educational, political, cultural and occupational organizations. This coordination was found especially fruitful; many controversial issues between the health workers and others, i.e. local dairy could be solved and unnecessary conversation avoided. Moreover, the coordination was even strengthened after the initial five-year program period. A new steering committee was assigned, having more non-medical representatives than before. Two 
new projects, also based strongly on intersectoral coordination were started. The other was cardiovascular diseases risk prevention in schools $(22,23)$ and the other community intervention on primary prevention of hypertension through salt intake reduction (24).

As seen from the answers of community decision makers they found it still necessary to develop cardiovascular diseases control activities in North Karelia. Health personnel was much more satisfied with the situation. This difference could be interpreted in a way that health services for cardiovascular diseases control may be adequate but there is still need to strengthen community involvement and intersectoral coordination.

\section{Exchange of information}

Much theory has been developed about the processess and mechanisms that operate between the community and the health services. Especially prevention programs depend on the extent of exchange of information. The health services must learn about the community: how it really works, what are its problems and needs. The community, on the other hand, has to learn about health matters: what are the causes of cardiovascular diseases and what are appropriate measures to prevent cardiovascular diseases and what are the purpose and nature of such measures that are recommended.

The exchange of information in the project was on continuous basis which could facilitate the joint action between the health services and the community. The massive number of articles, 1509 in country's newspapers, show that project was able to attract intense and frequent attention from the news in the area. In addition, over half million health education materials were distributed and 251 health education meetings were organized by many different groups. At the same time it was emphasized the importance of interpersonal communication, especially during the contacts of health personnel with people.

The outcome of this comprehensive exchange of information was positive; health knowledge among North Karelian population increased significantly. And as elsewhere presented the program resulted also a decrease of various psychosomatic symptoms in the population (25).

\section{Changed role of health workers}

It has been shown previously, and our results from North Karelia confirm that community has to be involved, if proper preventive health care is to be provided. Since in Finland the community is involved in the management of health services, the role and attitude of health workers has developed in a way that they can work with the community as an equal partner. This changing role was emphasized in the National Public Health Act, which at least in North Karelia, resulted a great progress.

The changed role of health workers is seen especially when looking at their par- 
ticipation in health education and intersectoral coordination. On the other hand, a strong request from the community will catalyse and motivate health professionals to develop their attitudes towards community involvement through natural process. This is, however, difficult if doctors are mainly concentrated in hospitals.

In North Karelia, partly due to shortage of doctors, the partnership between health services and the community was developed having public health nurses as a linkage group. This kind of approach was previously found effective in reducing maternity and infant mortality to the lowest level in the world and in controlling the mass epidemic of tuberculosis in Finland. Now, this linkage was proved as effective in cardiovascular diseases prevention and control, including hypertension control, antismoking and nutrition health education, etc.

There are always major implications for health manpower development. However, the main question is whether the health personnel is willing or able to provide the type of health care that permits community involvement and participation. In North Karelia they understood the extent of the problem. However, some doctors had personal reservations about the intervention, especially about the effectiveness of this approach and about the cardiovascular diseases factors in general. In any case, the generally positive attitudes were experienced during the program and were shown by their participation in the organized training and initiation of new programs. The positive attitudes were finally confirmed at the survey among health personnel in 1977.

\section{Impact on health}

It can be generally concluded that the health services in North Karelia concerning cardiovascular diseases control had improved through community involvement. Secondly, health behaviour indicators during the program showed a clear and permanent improvement. Naturally, the real impact on health would be the main goal and will be described separately. However, mention has been previously made of the need to monitor the involvement process so that progress in all aspects of the program could be measured.

For the present, the justification for this new community-based approach to cardiovascular diseases control is provided by the success achieved in North Karelia. Several other programs of similar type will provide us with more comprehensive understanding about cardiovascular diseases prevention, health services and community involvement that could be, hopefully, used in the future as a basic information for other non-communicable disease control programs.

\section{References}

1. WHO: Alma-Ata: Primary health care. WHO, Geneva, 1978.

2. Ovcarov V. and Bystrova V.: Present trends in mortality in the age group $35-64$ in selected developed countries between 1950-73. World Health Statistics Quarterly 1978: 31: 208. 
3. Dawber T.R., Meadors G.F. and Moore F.E.: Epidemilogical approaches to heart diseases. The Framingham Study. American Journal of Public Health 1951: 41: 279-286.

4. Keys A.: Coronary heart disease in seven countries. American Heart Association Monograph No 29, New York, 1970.

5. Puska P.: The North Karelia Project. An attempt at community prevention of cardiovascular disease. WHO Chronicle 1973: 27: 55-58.

6. Community involvement in primary health care: A study of the process of community motivation and continued participation. Report for the 1977 UNICEF/WHO Joint Committee on Health Policy. (JC 21/UNICEF-WHO/77.2. Rev. 2).

7. World Health Organization: Community involvement in the development of health services. WHO/WPRO, WPR/RC 31/TP/1, Manila 1980.

8. Puska P., Tuomilehto J., Salonen J., Nissinen A., Virtamo J., Björkqvist S., Koskela K., Neittaanmäki L., Takalo T., Kottke T.E., Mäki J., Sipilä P., Varvikko P.: The North Karelia Project. Community control of cardiovascular diseases. WHO/EURO, Copenhagen 1981.

9. Puska P., Tuomilehto J., Salonen J., Neittaanmäki L., Mäki J., Virtamo J., Nissinen A., Koskela $\mathrm{K}$., Takalo T.: Changes in coronary risk factors during comprehensive five-year community programme to cardiovascular diseases during 1972-1977 in North Karelia. The British Medical Journal 1979: 2: 1173-1178.

10. McAlister A., Puska P., Salonen J.T., Tuomilehto J. and Koskela K.: Theory and action for health promotion: illustrations from the North Karelia Project. American Journal of Public Health 1982: 72: $43-50$.

11. Puska P.: The North Karelia Project: health promotion in action. In: Lorenz KY and Deura LD (eds.). Strategies for Public Health. Van Nostrand Company, New York 1981, pp. 317-335.

12. Kannisto V.: Kuolemansyyt väestöllisinä tekijöinä Suomessa. Kansantaloudellisia tutkimuksia XV. Helsinki 1947.

13. Härö S.: Kuolleisuus Suomessa ja muissa Pohjoismaissa 1948 - 1964. Duodecim 1966: 82: 1136-1151.

14. Leppo K., Lindgren J. and Ritamies M.: Mortality trends in Finland in the 1960's. In: Yearbook of Population Research in Finland XII, 1971. Vammala 1972.

15. Puska P.: Regional differences in CVD mortality in Finland. Suomen Lääkärilehti 1972: 27: 3071-3075

16. Purola T., Nyman K., Kalimo E. ja Sievers K.: Sairausvakuutus, sairastavuus ja lääkintäpalvelusten käyttö. Kansaneläkelaitoksen julkaisuja A: 7, Helsinki 1971.

17. Harni A-L.: Sairauksien kehityksen alueittainen vaihtelu Suomessa. Kansaneläkelaitoksen julkaisuja A: 10, Helsinki 1973.

18. Puska P., Neittaanmäki L. and Tuomilehto J.: Survey of local health personnel and decision makers concerning the North Karelia Project: a community program for control of cardiovascular diseases. Preventive Medicine 1981: 10: 564-576.

19. Puska P., Vienola P., Kottke T.E., Salonen J.T. and Neittaanmäki L.: Health knowledge and community prevention of coronary heart disease. International Journal of Health Education 1981: 24 (suppl.).

20. Neittaanmäki L., Koskela K., Puska P. and McAlister A.: The role of lay workers in community health education: experiences of the North Karelia Project. Scandinavian Journal of Social Medicine 1980: 8: 1-7.

21. Kottke T.E., Puska P., Feldman R. and Tuomilehto J.: Emotional effects associated with a community-based heart disease prevention program. Preventive Medicine 1980: 9: 441.

22. Puska P., Vartiainen E., Pallonen U., Ruotsalainen P., Tuomilehto J., Koskela K. ja Norppa J.: Pohjois- Karjalan nuorisoprojekti: sydän- ja verisuonitautien riskitekijöiden ehkäisy 13-15-vuotiailla nuorilla. Tutkimusasetelma ja peruskartoituksen tuloksia. Sosiaalilääketieteellinen aikakauslehti 1980: 17 (5-6): 234-242.

23. Puska P., Vartiainen E., Pallonen U., Ruotsalainen P., Tuomilehto J., Koskela K., Lahtinen A. and Norppa J.: The North Karelia Youth Project. A community-based intervention study on CVD 
risk factors among 13- to 15-year-old children: study design and preliminary findings. Preventive Medicine 1981: 10: 133-148.

24. Tuomilehto J., Puska P., Tanskanen A., Karppanen H., Pietinen P., Nissinen A., Enlund H. and Ruotsalainen P.: A community-based intervention study on the feasibility and effects of the reduction of salt intake in North Karelia, Finland. Acta Cardiologica 1981: 2: 83-104.

25. Kottke T.E., Tuomilehto J., Puska P. and Salonen J.T.: The relationship of symptoms and blood pressure in a population sample. International Journal of Epidemiology 1979: 8: 355-359. 